\title{
Effects of flow fluctuations on the daily and seasonal drift of invertebrates in a tropical river
}

\author{
Diego M. P. Castro ${ }^{1 *}$, Robert M. Hughes ${ }^{1,2}$ and Marcos Callisto ${ }^{1}$ \\ 1 Laboratório de Ecologia de Bentos, Departamento de Biologia Geral, Instituto de Ciências Biológicas, Universidade Federal \\ de Minas Gerais, Av. Antônio Carlos, 6627, CP. 486, Pampulha, CEP 30161-970 Belo Horizonte, MG, Brazil \\ 2 Amnis Opes Institute and Department of Fisheries and Wildlife, Oregon State University, Corvallis, Oregon, USA
}

Received 27 November 2012; Accepted 15 May 2013

\begin{abstract}
Invertebrate drift results from several factors, including accidental dislodgement from the substratum, interaction with other invertebrates and predators, and changes in water quality, discharge and current velocity. We evaluated the degree to which flow fluctuations from dam releases altered the daily and seasonal invertebrate drift patterns in a tropical river. We collected macroinvertebrates during fixed flow rates $\left(323 \mathrm{~m}^{3} \cdot \mathrm{s}^{-1}\right.$ in the wet season and $111 \mathrm{~m}^{3} \cdot \mathrm{s}^{-1}$ in the dry season) and when peak flows fluctuated (378-481 $\mathrm{m}^{3} . \mathrm{s}^{-1}$ in the wet season and $109-173 \mathrm{~m}^{3} . \mathrm{s}^{-1}$ in the dry season) in 2010. Of the 31924 organisms collected, 8872 individuals and 43 taxa were collected in the wet season and 23052 and 32 taxa were collected during the dry season. Seasonality had a strong influence on invertebrate assemblage composition and structure in the drift. During fixed flow periods, drift densities were greatest in the dry season and drift taxonomic richness was greatest in the wet season. In the wet season, fluctuating flows increased nocturnal drift density and richness, but decreased diurnal richness; in the dry season, fluctuating flows decreased drift densities and diurnal richness. In conclusion, the daily and seasonal invertebrate drift patterns are influenced by dam operations that alter flows and this knowledge can be used to reduce the downstream effects of dams.
\end{abstract}

Key words: Hydropeaking / aquatic insects / dams / flow changes

\section{Introduction}

Macroinvertebrate drift is the downstream transport of aquatic invertebrates by the current (Brittain and Eikeland, 1988). The entry of invertebrates into the water column may result from several factors (Cowell and Carew, 1976), including accidental dislodgement from the substratum (Poff and Ward, 1991), interaction with other invertebrates and predators (Huhta et al., 2000), and changes in water quality, discharge and current velocity (Brittain and Eikeland, 1988).

Seasonal patterns in invertebrate drift can result from changes in benthic density, species life cycles and seasonal changes in water temperature and flow (Elliott, 1968; Hildebrand, 1974; Brittain and Eikeland, 1988). Diel drift periodicity is usually related to the presence of predators and the circadian rhythms of invertebrates (Waters, 1972; Flecker, 1992; Ramírez and Pringle, 2001).

Some studies suggest that drift dynamics in tropical streams are similar to those in temperate regions (Ramírez and Pringle, 1998), such as the nocturnal diel periodicity in

\footnotetext{
*Corresponding author: diegobioufla@gmail.com
}

streams where diurnal predators are present (Flecker, 1992). In contrast to temperate regions, tropical drift is generally non-seasonal (Ramírez and Pringle, 2001; Jacobsen and Bojsen, 2002), but does increase with high flow events (Ríos-Touma et al., 2012). Recent studies have focused on tropical stream drift (Callisto and Goulart, 2005; Lobón-Cerviá et al., 2012; Ríos-Touma et al., 2012), but drift studies are scarce in large rivers, especially regarding the effects of fluctuating discharges.

The influence of flow fluctuations downstream of reservoirs is a major challenge for the conservation and management of freshwater ecosystems (Acreman and Ferguson, 2010). During the period of highest energy demand, power is generated and water is rapidly released producing much higher and faster flows that fluctuate daily (Jones, 2013). These fluctuating discharges below impoundments may alter benthic invertebrate assemblages downstream, as a result of higher velocities, increased bed instability, and altered water temperature and quality, leading to higher invertebrate drift rates (Troelstrup and Hergenrader, 1990; Bruno et al., 2009; Smokorowski et al., 2011). Flows created by dam operations modulate natural seasonal extremes, and reduce flood frequency, duration 


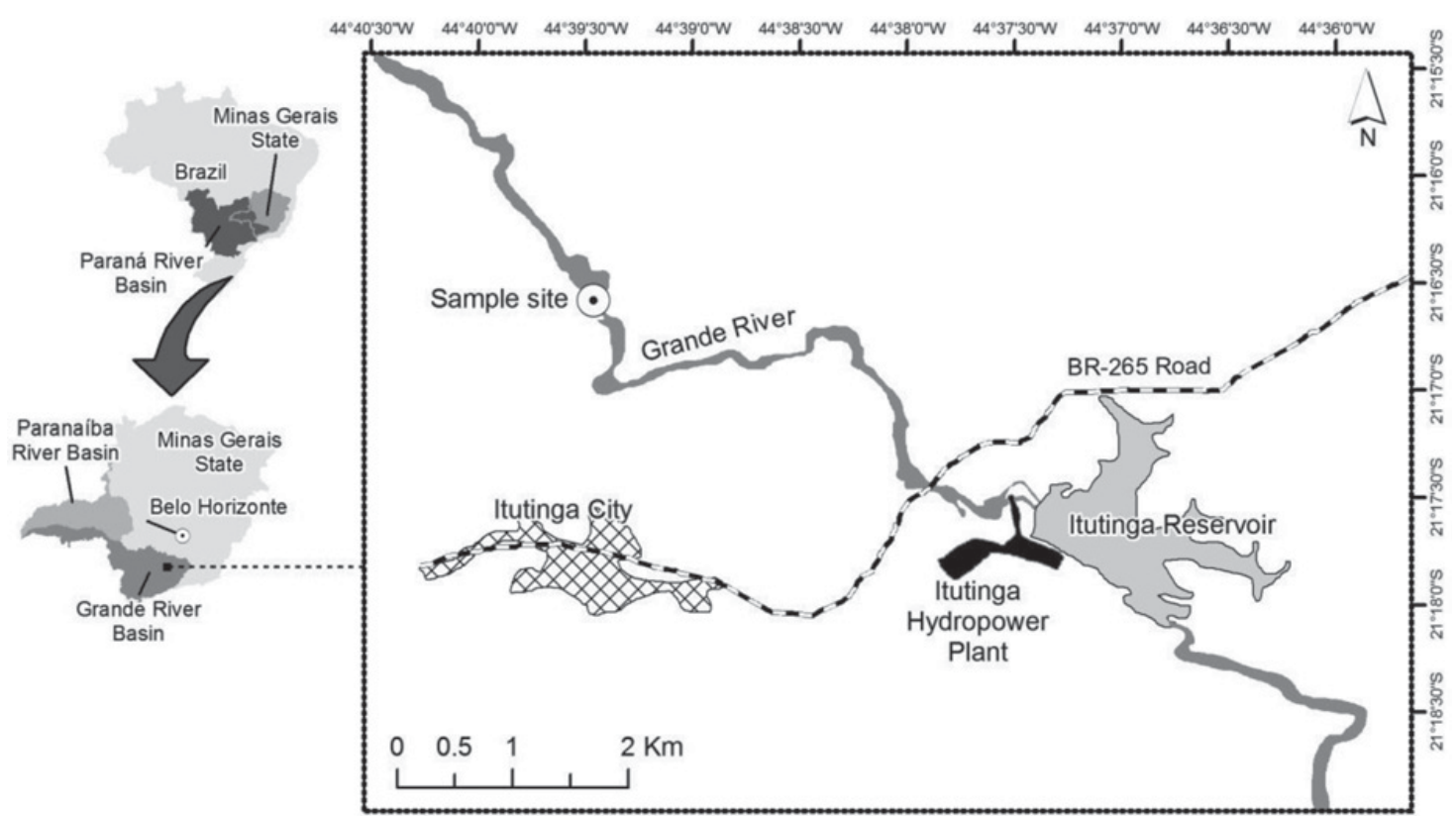

Fig. 1. Study area and drift sampling location in the Rio Grande downstream of Itutinga Hydroelectric Power Plant, Minas Gerais, Brazil.

and predictability (Poff et al., 1997; Bunn and Arthington, 2002), affecting aquatic biological conditions downstream of dams (Poff and Zimmerman, 2010).

Therefore, the objective of this study was to investigate the degree to which flow fluctuations alter daily and seasonal invertebrate drift patterns in a tropical river. We hypothesized that fluctuating discharges would (1) increase drift density and richness, and (2) alter invertebrate taxonomic composition between periods of fixed and fluctuating flows in both seasons.

\section{Material and methods}

\section{Study area}

The study site was $5 \mathrm{~km}$ downstream of the Itutinga Hydroelectric Power Plant (IHPP) in a $150 \mathrm{~m}$ wide reach of the upper Rio Grande, Minas Gerais, Brazil. The Rio Grande rises in the Serra da Mantiqueira, on the border of the states of Minas Gerais and São Paulo, flows $1300 \mathrm{~km}$ to the Rio Paranaíba (Fig. 1), and much of the river's flow is used to generate hydropower. The river flows through cerrado (savanna) vegetation where average annual temperature is $19-21^{\circ} \mathrm{C}$ and the climate is semihumid, with 4-5 months of drought, a 6-month rainy season, and mean annual rainfall of 1200-1500 mm (Pompeu et al., 2009).

\section{Hydraulic experiments}

For the hydraulic experiments and drift sampling we considered four different treatments in 2010: wet season with fixed flow $\left(323 \mathrm{~m}^{3} \cdot \mathrm{s}^{-1}\right)$, wet season with fluctuating flow $\left(378-481 \mathrm{~m}^{3} \cdot \mathrm{s}^{-1}\right)$, dry season with fixed flow $\left(111 \mathrm{~m}^{3} \cdot \mathrm{s}^{-1}\right)$, and dry season with fluctuating flow $\left(109-173 \mathrm{~m}^{3} \cdot \mathrm{s}^{-1}\right)$. The Companhia Energética de Minas Gerais (CEMIG) manipulated IHPP flows based on the historical monthly average for the river in the 20 years before dam construction. In each sampling period, flows were held constant for 34 consecutive days at the historical monthly average for the river $\left(323 \mathrm{~m}^{3} . \mathrm{s}^{-1}\right.$ for the wet season and $111 \mathrm{~m}^{3} \cdot \mathrm{s}^{-1}$ for the dry season). After the constant flow periods, IHPP fluctuated peak flows for 4 days. The onset of increased flows began at 17:00, and reached a maximum at 18:30. At 21:00, flows began being reduced, returning to the average monthly flows described above at 23:00. This range of increased flows was chosen because it is the time of highest energy demand when the plant is working at full capacity.

\section{Drift sampling}

We collected daily invertebrate drift samples during the last 4 days of the constant flow periods and during the 4 days of peaking flows through use of 3 nets $(40 \times 40 \mathrm{~cm}$ opening; $1 \mathrm{~m}$ length, $250 \mu \mathrm{m}$ mesh) placed in areas with laminar flow. The nets were fixed on the substrate through use of steel bars and remained in place $24 \mathrm{~h} . \mathrm{d}^{-1}$ with individual samples removed every $8 \mathrm{~h}$ (23:00-07:00, 07:00-15:00, 15:00-23:00). In total, we collected 3 nets $\times 3$ times $/$ day $\times 4$ days $\times 4$ treatments $=144$ samples. Days were our replicates for seasonal variation and samples taken at the same hours in different days were our replicates for daily drift variation.

The material retained in the nets was removed, washed through a $250 \mu \mathrm{m}$ sieve, placed in vials with $70 \%$ alcohol, and returned to the laboratory for sorting. We identified 
Table 1. Water quality (mean \pm SD) during the wet (January) and dry (July) seasons in the Rio Grande, downstream of Itutinga Hydroelectric Power Plant, Minas Gerais, Brazil.

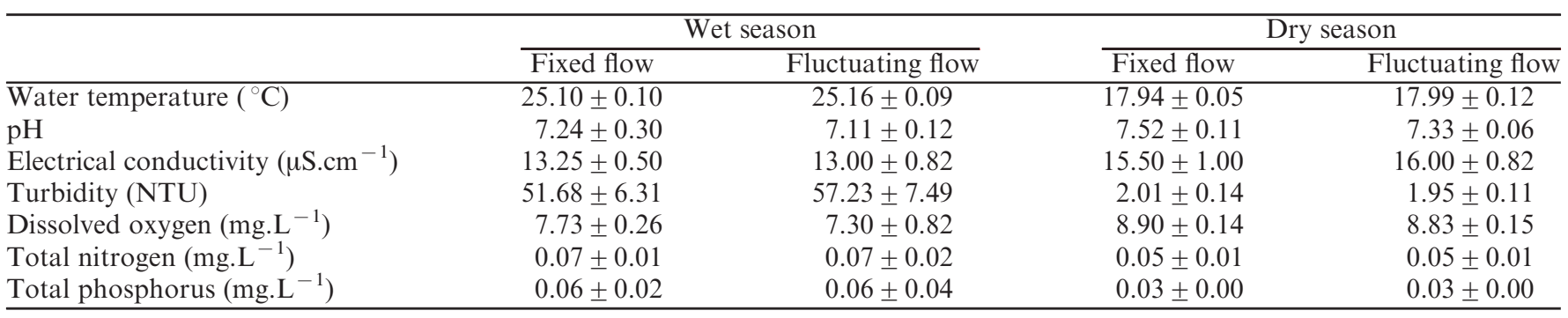

aquatic individuals to family through use of Pérez (1988), Merritt and Cummins (1996), and Mugnai et al. (2010). Average current velocity $\left(\mathrm{m} . \mathrm{s}^{-1}\right)$ was measured with a Global Flow Probe at each net mouth at the beginnings and ends of the three daily $8 \mathrm{~h}$ sampling periods, every day. The filtered volumes $\left(\mathrm{m}^{3}\right)$ through each of the three nets were calculated by multiplying the net submerged area by the average water velocity by the sampling time. The densities of organisms in the drift were recorded as the number of invertebrates per $100 \mathrm{~m}^{3}$ filtered water (Allan and Russek, 1985).

To assess the propensity of invertebrates to drift, we applied the formula: drift density/benthic density (McIntosh et al., 2002) using the mean values of drift density and benthic density for each day between the seasons. The benthic mean densities were obtained from a simultaneously study conducted at the same location during the same period of this work. Sediment samples were collected with a Petersen dredge in three different habitats upstream the drift nets. For the calculation, we excluded Chaoboridae larvae, because these organisms are lentic and probably carried from upstream Itutinga Reservoir.

\section{Water quality}

During the four treatment periods, we measured water quality variables daily at the drift nets. Water temperature $\left({ }^{\circ} \mathrm{C}\right)$, electrical conductivity $\left(\mu \mathrm{S} . \mathrm{cm}^{-1}\right), \mathrm{pH}$, and turbidity (NTU) were measured through use of a YSI 6600 multiprobe. We determined total phosphorus $\left(\mathrm{mg} . \mathrm{L}^{-1}\right)$, total nitrogen $\left(\mathrm{mg} . \mathrm{L}^{-1}\right)$, and dissolved oxygen $\left(\mathrm{mg} . \mathrm{L}^{-1}\right)$ in the laboratory following standard methods (APHA, 1992).

\section{Data analyses}

Taxonomic richness was estimated as the total number of different taxa per sample. Similarity Analysis (ANOSIM) was performed to test differences in taxonomic composition between wet and dry seasons with fixed and fluctuating flows. We used Nonmetric multidimensional scaling (NMDS) to plot results from a BrayCurtis dissimilarity matrix on square root transformed abundance data. Both NMDS and ANOSIM were performed with PRIMER 6.0 + PERMANOVA software (Clarke and Warwick, 2001).

Differences in richness and density values between the wet and dry seasons and between the daily sample times within each season were compared by one-way ANOVAs. We used the Tukey post-hoc test to identify differences between the factors when tests were significant $(P<0.05)$. We also evaluated differences in water quality variables and differences in drift propensity between and within the wet and dry seasons through use of one-way ANOVAs. Data were square root transformed when necessary to meet assumptions of normality (Kolmogorov-Smirnov) and homogeneity of variances (Zar, 1996). We conducted these tests with Statistica 8.0 software.

\section{Results}

\section{Water quality}

All the water quality variables measured were significantly different between wet and dry seasons. Temperature (ANOVA, $F_{1,14}=2656.50, P<0.001$ ), turbidity $\left(F_{1,14}=441.42, P<0.001\right)$, total-N $\left(F_{1,14}=8.92\right.$, $P=0.009)$ and total-P $\left(F_{1,14}=9.01, \quad P=0.009\right)$ were significantly higher in the wet season (Table 1). Electrical conductivity $\left(F_{1,14}=46.07, P<0.001\right)$, dissolved oxygen $\left(F_{1,14}=37.69, P<0.001\right)$, and $\mathrm{pH}\left(F_{1,14}=7.53, P=0.016\right)$, were significantly higher in the dry season (Table 1). Those variables showed no significant differences between periods of fixed and fluctuating flow in the wet season; however, $\mathrm{pH}$ was significantly lower during periods of fluctuating flows in the dry season $\left(F_{1,6}=9.54, P=0.021\right)$.

\section{Seasonal changes in invertebrate drift}

Season had a strong influence on drifting invertebrate assemblage composition and structure. Of the 31924 organisms collected, 8872 individuals and 43 taxa were collected in the wet season and 23052 individuals and 32 taxa were collected during the dry season. Hydropsychidae $(30.4 \%)$, Chaoboridae (25.1\%), Simuliidae (17.1\%), Chironomidae (11.1\%), Leptohyphidae (4.2\%) and Polycentropodidae $(3.7 \%)$ were the most abundant taxa in the wet season drift. During the dry season, the most 

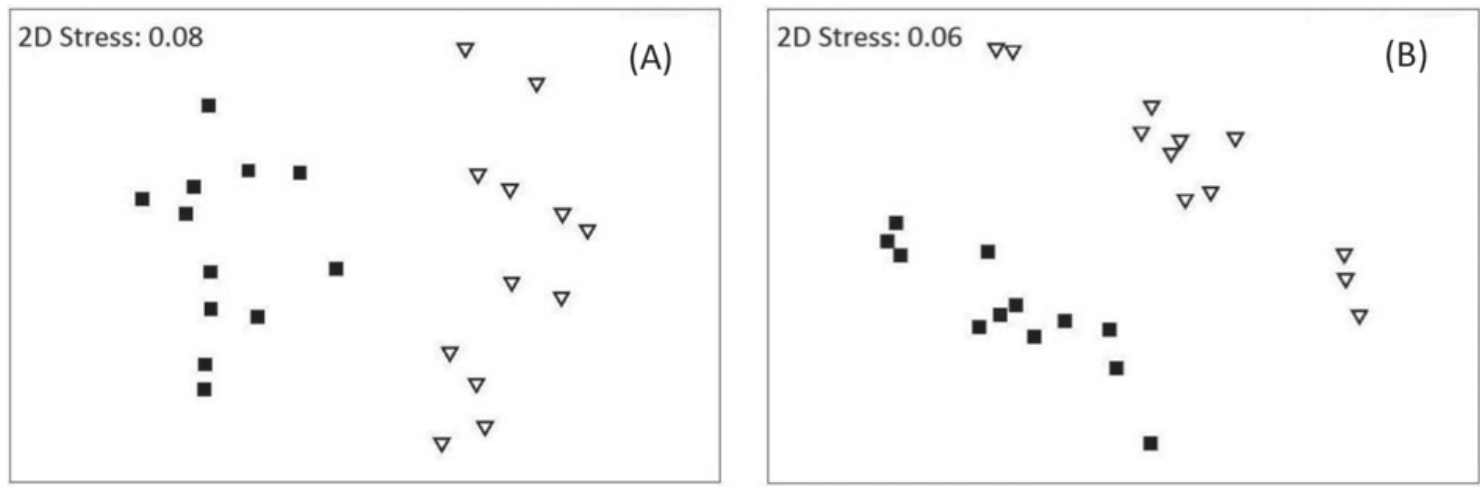

Fig. 2. NMDS of the taxonomic composition of drifting macroinvertebrates comparing the seasons with fixed flow (A) and seasons with fluctuating flow (B) treatments. Wet season, squares; dry season, triangles.
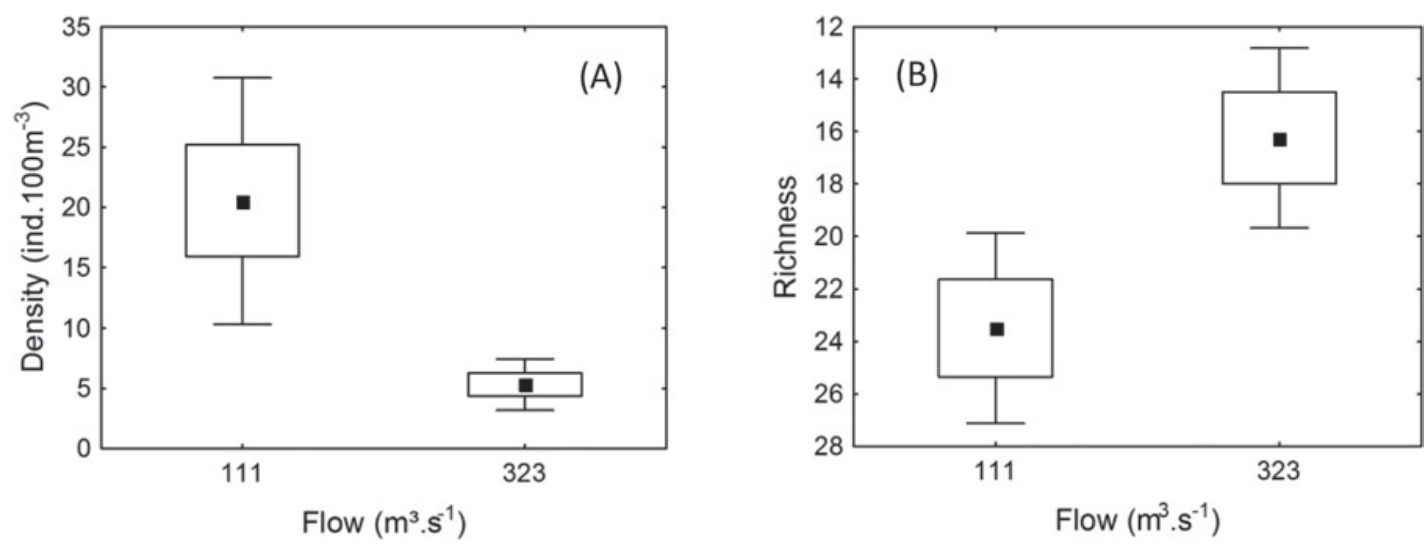

Fig. 3. Density (A) and taxonomic richness (B) differences (means, standard errors, 95\% confidence intervals) of drifting macroinvertebrates comparing wet and dry season with fixed flow.

abundant taxa in the drift were Simuliidae (90.1\%), Chironomidae $(2.9 \%)$, Chaoboridae $(1.7 \%)$, Leptophlebiidae (1.66\%) and Hydropsychidae (1.0\%).

The NMDS and similarity analysis showed significant differences in drift taxonomic composition between the dry and wet seasons both for fixed flows (ANOSIM, $R=0.969, P<0.001$ ) (Fig. 2(A)) and for fluctuating flows (ANOSIM, $R=0.955, P<0.001$ ) (Fig. 2(B)). This indicates changes in the taxonomic composition in the drift assemblages between seasons, both for fixed and fluctuating flows.

During the fixed flows, drift densities were greatest in the dry season (ANOVA, $F_{1,22}=10.34, P=0.004$ ) (Fig. 3(A)) and taxonomic richness $\left(F_{1,6}=8.11\right.$, $P=0.029)$ was significantly higher in the wet season (Fig. 3(B)). During fluctuating flows, we found no significant differences in observed richness or density between dry and rainy seasons.

The drift propensity values did not show significant differences between fixed and fluctuating flows in or between the wet and dry seasons although the composition of benthos and drift samples differed. In the wet season, 20 of the 43 taxa present in drift samples were absent from benthic samples, and in the dry season, 12 of the 32 taxa present in the drift samples were absent from benthic samples (Table 2).

\section{Daily drift variation}

Drift densities and richness varied with the time of day in both seasons. In the wet season with fixed flow, there were no significant differences in invertebrate densities or richness between sampling times (Fig. 4). However, during fluctuating flows density (one-way ANOVA, $F_{2,9}=15.670$, $P=0.001)$ and richness $\left(F_{2,9}=10.311, P=0.0047\right)$ were higher in samples from 23:00 to 7:00 $\mathrm{h}$ than in the 7:0015:00 $\mathrm{h}$ and 15:00-23:00 $\mathrm{h}$ sampling periods (Fig. 4). In the dry season with fixed flow (Fig. 5), invertebrate densities were higher in the 23:00-7:00 $\mathrm{h}$ and 15:00-23:00 $\mathrm{h}$ samples (one-way ANOVA, $F_{2,9}=7.802, p=0.011$ ) and richness was greater in the 23:00-7:00 $\mathrm{h}$ samples (one-way ANOVA $\left., \quad F_{2,9}=5.257, \quad P=0.031\right)$. With fluctuating flows there were no significant differences in invertebrate densities between sampling times $\left(F_{2,9}=3.057, P=0.097\right)$ (Fig. 5(A)); however, richness was higher in the 23:00-7:00 $\mathrm{h}$ and $15: 00-23: 00 \mathrm{~h}$ samples $\left(F_{2,9}=5.626, P=0.026\right)$ (Fig. 5(B)). 
Table 2. Benthos and drift densities and drift propensity of taxa present in both wet and dry seasons.

\begin{tabular}{|c|c|c|c|c|c|c|}
\hline \multirow[b]{2}{*}{ Taxa } & \multicolumn{2}{|c|}{ Benthos density (ind.m ${ }^{-2}$ ) } & \multicolumn{2}{|c|}{ Drift density (ind. $\mathrm{m}^{-3}$ ) } & \multicolumn{2}{|c|}{ Drift propensity } \\
\hline & Wet & Dry & Wet & Dry & Wet & Dry \\
\hline Amphipoda* & 0.000 & 0.391 & 0.00000 & 0.00000 & - & 0.00000 \\
\hline Baetidae & 6.771 & 0.911 & 0.00072 & 0.00165 & 0.00011 & 0.00181 \\
\hline Caenidae** & 0.000 & 0.000 & 0.00001 & 0.00002 & - & - \\
\hline Canacidae** & 0.000 & 0.000 & 0.00003 & 0.00000 & - & - \\
\hline Ceratopogonidae & 0.391 & 4.167 & 0.00004 & 0.00023 & 0.00011 & 0.00005 \\
\hline Chironomidae & 175.130 & 1050.911 & 0.01104 & 0.00756 & 0.00006 & 0.00001 \\
\hline Chrysomelidae** & 0.000 & 0.000 & 0.00003 & 0.00000 & - & - \\
\hline Coenagrionidae** & 0.000 & 0.000 & 0.00003 & 0.00002 & - & - \\
\hline Collembola** & 0.000 & 0.000 & 0.00003 & 0.00014 & - & - \\
\hline Culicidae** & 0.000 & 0.000 & 0.00001 & 0.00000 & - & - \\
\hline Elateridae** & 0.000 & 0.000 & 0.00001 & 0.00000 & - & - \\
\hline Elmidae & 1.563 & 2.214 & 0.00092 & 0.00019 & 0.00059 & 0.00009 \\
\hline Empididae & 0.521 & 0.130 & 0.00018 & 0.00015 & 0.00034 & 0.00113 \\
\hline Gelastocoridae* & 0.130 & 0.000 & 0.00000 & 0.00000 & 0.00000 & - \\
\hline Gerridae & 0.000 & 0.391 & 0.00001 & 0.00001 & - & 0.00003 \\
\hline Gomphidae & 0.521 & 0.130 & 0.00011 & 0.00003 & 0.00022 & 0.00026 \\
\hline Gripopterygidae** & 0.000 & 0.000 & 0.00004 & 0.00001 & - & - \\
\hline Gyrinidae** & 0.000 & 0.000 & 0.00001 & 0.00001 & - & - \\
\hline Hidracarina & 0.130 & 0.000 & 0.00010 & 0.00003 & 0.00078 & - \\
\hline Hirudinea** & 0.000 & 0.000 & 0.00003 & 0.00000 & - & - \\
\hline Hydrophilidae & 1.042 & 0.000 & 0.00006 & 0.00000 & 0.00005 & - \\
\hline Hydropsychidae & 56.771 & 9.766 & 0.03031 & 0.00270 & 0.00053 & 0.00028 \\
\hline Hydroptilidae & 14.063 & 1.042 & 0.00208 & 0.00061 & 0.00015 & 0.00058 \\
\hline Lampyridae** & 0.000 & 0.000 & 0.00001 & 0.00000 & - & - \\
\hline Leptoceridae & 0.260 & 0.260 & 0.00012 & 0.00025 & 0.00047 & 0.00095 \\
\hline Leptohyphidae & 14.193 & 37.891 & 0.00415 & 0.00245 & 0.00029 & 0.00006 \\
\hline Leptophlebiidae & 0.260 & 0.521 & 0.00273 & 0.00432 & 0.01047 & 0.00829 \\
\hline Libellulidae & 0.130 & 1.432 & 0.00011 & 0.00021 & 0.00086 & 0.00015 \\
\hline Lutrochidae** & 0.000 & 0.000 & 0.00001 & 0.00000 & - & - \\
\hline Muscidae** & 0.000 & 0.000 & 0.00001 & 0.00000 & - & - \\
\hline Naucoridae** & 0.000 & 0.000 & 0.00011 & 0.00001 & - & - \\
\hline Nematoda & 0.000 & 1.172 & 0.00000 & 0.00001 & - & 0.00001 \\
\hline Notonectidae** & 0.000 & 0.000 & 0.00003 & 0.00001 & - & - \\
\hline Odontoceridae** & 0.000 & 0.000 & 0.00001 & 0.00000 & - & - \\
\hline Oligochaeta & 16.406 & 19.271 & 0.00007 & 0.00006 & 0.00000 & 0.00000 \\
\hline Ostracoda* & 0.521 & 0.000 & 0.00000 & 0.00000 & 0.00000 & - \\
\hline Perlidae** & 0.000 & 0.000 & 0.00002 & 0.00000 & - & - \\
\hline Philopotamidae** & 0.000 & 0.000 & 0.00004 & 0.00006 & - & - \\
\hline Polycentropodidae & 2.083 & 0.911 & 0.00325 & 0.00039 & 0.00156 & 0.00043 \\
\hline Polymitarcyidae & 0.130 & 0.000 & 0.00025 & 0.00008 & 0.00190 & - \\
\hline Psychodidae** & 0.000 & 0.000 & 0.00013 & 0.00002 & - & - \\
\hline Pyralidae & 4.557 & 0.521 & 0.00033 & 0.00005 & 0.00007 & 0.00009 \\
\hline Simuliidae & 19.010 & 2.474 & 0.01703 & 0.23420 & 0.00090 & 0.09467 \\
\hline Staphylinidae** & 0.000 & 0.000 & 0.00002 & 0.00001 & - & - \\
\hline Sysiridae** & 0.000 & 0.000 & 0.00000 & 0.00002 & - & - \\
\hline Tabanidae & 0.000 & 0.000 & 0.00002 & 0.00000 & - & - \\
\hline Tipulidae & 0.521 & 1.563 & 0.00002 & 0.00000 & 0.00004 & 0.00000 \\
\hline Vellidae & 0.391 & 0.000 & 0.00019 & 0.00005 & 0.00049 & - \\
\hline
\end{tabular}

*Taxa present only in benthos samples; **taxa present only in drift samples.

\section{Discussion}

We found strong seasonal variations in the taxonomic composition and density of invertebrates in the drift. Flow fluctuations influenced macroinvertebrate drift, but we did not observe a recurring pattern of daily drift variation. Information about drift dynamics in tropical rivers is limited to a few geographical areas (Ramírez and Pringle,
1998) and small streams (Callisto and Goulart, 2005). Studies evaluating the drift dynamics in large rivers and hydraulic experiments are scarce in the tropics (LobónCerviá et al., 2012). The opportunity to manipulate the flow downstream of a hydroelectric plant, in which was a unique opportunity for a large tropical river, allowed us to evaluate the influence of daily fluctuations in macroinvertebrate drift. 

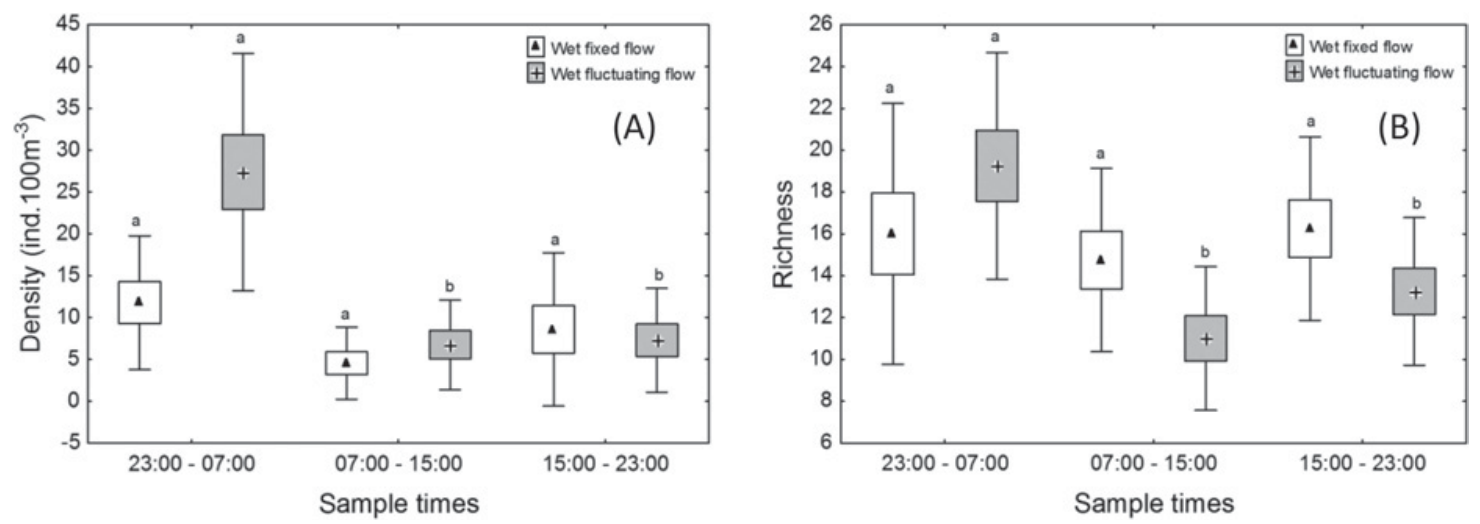

Fig. 4. Density (A) and richness (B) differences (means, standard errors, 95\% confidence intervals) of drifting macroinvertebrates comparing sample times between periods of fixed and fluctuating flows in the wet season. $b$, significant difference.
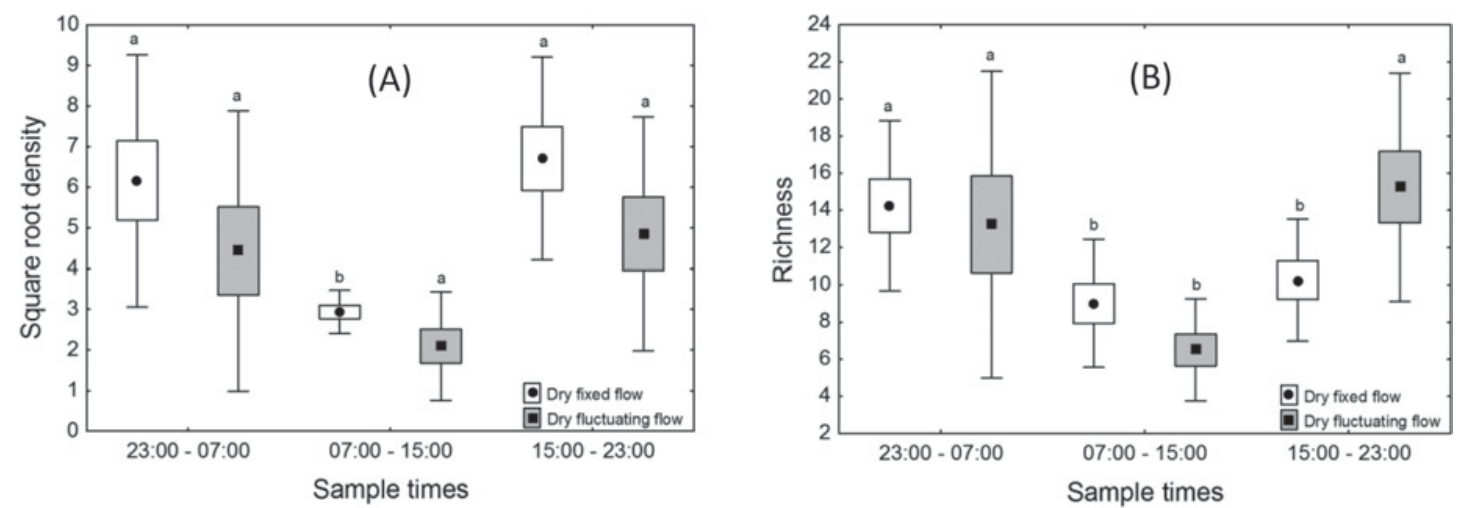

Fig. 5. Density (A) and richness (B) differences (means, standard errors, 95\% confidence intervals) of drifting macroinvertebrates comparing sample times between periods of fixed and fluctuating flows in the dry season. $b$, significant difference.

Flow fluctuations resulting from the plant operation in both dry and rainy seasons did not cause significant changes in water quality downstream of the dam. However, Naliato et al. (2009) observed limnological differences downstream of dams associated with daily flow variation. The IHPP has a small reservoir $\left(7 \mathrm{hm}^{3}\right.$ useful volume) and water is stored for short periods. Generally, deep and high residence time reservoirs tend to exhibit sharp thermal and chemical stratification (Straskraba, 1999), which was not the case for the IHPP reservoir. The differences in water quality between seasons are directly related to precipitation. In the warm rainy season, there is an increased flow of warmer water from tributaries feeding the reservoir, and carrying larger concentrations of allochthonous sediment and organic matter and leading to increased temperature, turbidity and nutrient concentrations (Table 1).

Unlike temperate regions where drift is minimal during the winter, seasonal variations in the drift may be less apparent or even absent in tropical and sub-tropical streams (Brittain and Eikeland, 1988; Ramírez and Pringle 2001). However, we found higher drift densities in the dry winter season than in the wet summer season (Fig. 3(A)), corroborating the findings of Cowell and Carew (1976) and Schreiber (1995). Furthermore, we observed significant differences in taxonomic composition between seasons (Fig. 2). We believe that different life history patterns related to the marked differences in environmental conditions (e.g., temperature, photoperiod, patterns of allochtonous input) found between the seasons are probably responsible for the differences in seasonal drift patterns that we observed (Cowell and Carew, 1976). The main difference between wet and dry seasons was the density of Simuliidae. In the dry season, they accounted for more than $90 \%$ of macroinvertebrate individuals, but only $17 \%$ in the wet season (Table 2). Probably these differences are related to their life cycle, reproductive periods, and population densities (Hamada et al., 2002). Moreover, several studies have demonstrated a high density of invertebrate filter feeders such as Simuliidae downstream of reservoirs, probably as a result of the supply of phytoplankton produced from those environments (Armitage, 1978). In general, higher phytoplankton densities are observed in periods of greater hydrodynamic stability in aquatic systems, usually in the dry season (Figueredo and Giani, 2001), favoring the colonization and persistence of filter feeding macroinvertebrate species. On the other hand, the increased flow velocities and turbidities of the wet season would hinder Simuliidae feeding and persistence. 
Flow fluctuations influenced the macroinvertebrate drift. When we compared the drift between seasons under fixed flow conditions, density was higher in the dry season and richness was higher in the wet season (Fig. 3). However, when we assessed the drift between the seasons under fluctuating flow conditions, no density or richness differences were observed. The increases in flow velocity and discharge during the wet season likely displaced both substrate and organisms (Brittain and Eikeland, 1988).

Although no significant differences were observed in the total drift propensity between the seasons, unlike that observed by Ríos-Touma et al. (2012), drift propensities of some taxa clearly differed between seasons (Table 2). The majority of taxa showed high drift propensity during the wet season, except Baetidae and Simuliidae which had higher drift propensity during the dry season. The differences in drift propensity values for taxa between seasons suggest that the high values observed in the wet season result from continuous displacement of the benthic assemblage, which can be interpreted as catastrophic drift.

The daily variation in the drift is a recurring pattern, with numerous studies showing that drift increases at night, especially just after sunset (Poff and Ward, 1991; Ramírez and Pringle, 1998; Hansen and Closs, 2007). Nevertheless, we did not observe a recurring pattern of daily drift in both wet and dry seasons. In the wet season with fixed flow, there were no significant differences in the drift between the different sample times. Lauters et al. (1996) observed that repeated peak flows from a dam altered the natural behavior of the drift, reducing nocturnal activity. In our wet season experiment, perhaps the 34-day flow stabilization period was not enough for the invertebrate assemblages to colonize and begin to display a standard daily periodicity to enter into the drift. However, in the dry season with fixed flow, we observed that density and richness drift increased at night. This may be related to high densities of invertebrates in the sediment, which due to intraspecific competition, tend to enter into the current. This entry into the drift occurs mainly at night, minimizing the chances of predation (Flecker, 1992).

On the other hand, in the wet season with fluctuating flow we observed higher densities and richness in samples taken from 23:00 to 7:00 h, just after the flood pulses. Unlike the expected drift increase under high flow conditions (Ramírez and Pringle, 2001), we found that the drift did not increase with flow, but did influence the behavior of aquatic invertebrates downstream of the dam. In the dry season, with fluctuating flows there were no differences in density between sampling times, but richness was higher in night samples. Invertebrates responded to the fluctuating flow periods with catastrophic drift, probably as a consequence of the sudden increase in bottom shear stress (Bruno et al., 2012). The difference in drift richness is a consequence of the sensitivity of each taxon to flow fluctuations, related to the degree of adaptation to resist increased current velocities or to move toward refuge habitats (Céréghino et al., 2002).
Some groups, such as Ephemeroptera, Plecoptera and Trichoptera, usually drift mostly at night, although some families of those orders may drift during the day (Brittain and Eikeland, 1988). In this study, we observed that some groups had daily variation in drift densities, but in no group did we observe a recurring pattern during the entire study. Thus, we highlight the importance of longterm studies at minimally disturbed river reference sites to better understand the behavior of invertebrates in the river drift. Moreover, the taxa richness collected through use of drift samples corroborates the importance of this sampling methodology, especially in large rivers (Flecker, 1992). Drift nets yield an integrated sample of various habitats and provide information about translocations in invertebrate assemblages (Ramírez and Pringle, 1998). In addition, drift samples typically are easier to process than benthic samples that contain considerable organic or inorganic materials.

Because of experimental and economic difficulties in manipulating flows at other hydroelectric dams, we could not replicate this study. However, we recommended implementing this approach to study invertebrates in drift downstream of other dams, so that data can be compared and impact biomonitoring methodologies can be established. A better understanding of the effects of anthropogenic flow fluctuations on aquatic invertebrates is needed, so that managers can reduce the downstream effects of dams on invertebrates and the fishes that prey on them.

\section{Conclusion}

The observed changes in the composition, richness and density of drift macroinvertebrates reflect the influence of fluctuating flows on drift patterns, corroborating our hypotheses. These changes may disturb the whole aquatic ecosystem, because macroinvertebrates influence important ecological processes such as nutrient cycling and trophic exchanges. Thus, drifting macroinvertebrates should be considered for management actions that could help mitigate hydropower impacts and in studies for developing environmental flows, because they may reflect ecological changes in biological communities.

Acknowledgements. We received funding and support for this research from ANEEL/Companhia Energética de Minas Gerais (CEMIG), Conselho Nacional de Desenvolvimento Científico e Tecnológico (CNPq) and Fulbright Brazil. Colleagues from the Laboratório de Ecologia de Bentos (UFMG) assisted with field collections. Discussions held during the Workshop on Ecological Assessment: the Foundation for Evaluating Biological Patterns (3-7 October 2011, US EPA Western Ecology Division, Corvallis, OR, USA) added further insights for this study. MC received a research grant and a research fellowship from the Conselho Nacional de Desenvolvimento Científico e Tecnológico (CNPq numbers 473966/2012-3, 471385/2011-5 and 302960/ 2011-2). 


\section{References}

Acreman M.C. and Ferguson J.D., 2010. Environmental flows and European Water Framework Directive. Freshwat. Biol., $55,32-48$.

Allan J.D. and Russek E., 1985. The quantification of stream drift. Can. J. Fish. Aquat. Sci., 42, 210-215.

American Public Health Association - APHA, 1992. Standard Methods for the Examination of Water and Wastewater, American Public Health Association, Washington.

Armitage P.D., 1978. Downstream changes in the composition, numbers and biomass of bottom fauna in the Tees River, below Cow Green Reservoir and in an unregulated tributary Maize Beck, in the first five years after impoundment. Hydrobiologia, 58, 145-156.

Brittain J.E. and Eikeland T.J., 1988. Invertebrate drift - a review. Hydrobiologia, 166, 77-93.

Bruno M.C., Maiolini B., Carolli M. and Silveri L., 2009. Impact of hydropeaking on hyporheic invertebrates in an Alpine stream (Trentino, Italy). Ann. Limnol. - Int. J. Lim., $45,157-170$.

Bruno M.C., Siviglia A., Carolli M. and Maiolini B., 2012. Multiple drift responses of benthic invertebrates to interacting hydropeaking and thermopeaking waves. Ecohydrol., in press. doi: 10.1002/eco.1275.

Bunn S.E. and Arthington A.H., 2002. Basis principles and ecological consequences of altered flow regimes for aquatic biodiversity. Environ. Manage., 30, 492-507.

Callisto M. and Goulart M., 2005. Invertebrate drift along a longitudinal gradient in a Neotropical stream in Serra do Cipó National Park, Brazil. Hydrobiologia, 539, 47-56.

Céréghino R., Cugny P. and Lavandier P., 2002. Influence of intermittent hydropeaking on the longitudinal zonation patterns of benthic invertebrates in a mountain stream. Int. Rev. Hydrobiol., 87, 47-60.

Clarke K.R. and Warwick R.M., 2001. Change in Marine Communities an Approach to Statistical Analysis and Interpretation (2nd edn), Primer-e Ltd., Plymouth Marine Laboratory, UK, 172 p.

Cowell B.C. and Carew W.C., 1976. Seasonal and diel periodicity in the drift of aquatic insects in a subtropical Florida stream. Freshwat. Biol., 6, 587-594.

Elliott J.M., 1968. The life histories and drifting of Trichoptera in a Dartmoor stream. J. Anim. Ecol., 37, 615-625.

Figueredo C.C. and Giani A., 2001. Seasonal variation in the diversity and species richness of phytoplankton in a tropical eutrophic reservoir. Hydrobiologia, 445, 165-174.

Flecker A.S., 1992. Fish predation and the evolution of invertebrate drift periodicity: evidence from Neotropical streams. Ecology, 73, 438-448.

Hamada N., McCreadie J.W. and Adler P.H., 2002. Species richness and spatial distribution of blackflies (Diptera: Simuliidae) in streams of Central Amazonia, Brazil. Freshwat. Biol., 47, 31-40.

Hansen E.A. and Closs G.P., 2007. Temporal consistency in the long-term spatial distribution of macroinvertebrate drift along a stream reach. Hydrobiologia, 575, 361-371.

Hildebrand S.G., 1974. The relation of drift to benthos density and food level in an artificial stream. Limnol. Oceaonogr., 19, 951-957.
Huhta A., Muotka T. and Tikkanen P., 2000. Nocturnal drift of mayfly nymphs as a post-contact antipredator mechanism. Freshwat. Biol., 45, 33-42.

Jacobsen D. and Bojsen B., 2002. Macroinvertebrate drift in Amazon streams in relation to riparian forest cover and fish fauna. Arch. Hidrobiol., 155, 177-197.

Jones N.E., 2013. The dual nature of hydropeaking rivers: is ecopeaking possible? River Res. Applic., in press. doi: 10.1002/rra.2653.

Lauters F., Lavandier P., Lim P., Sabaton C. and Belaud A., 1996. Influence of hydropeaking on invertebrates and their relationship with fish feeding habits in a Pyrenean River. Regul. River., 12, 563-573.

Lobón-Cerviá J., Rezende C.F. and Castellanos C., 2012. High species diversity and low density typify drift and benthos composition in Neotropical streams. Fund. Appl. Limnol., 181, 129-142.

McIntosh A.R., Peckarsky B.L. and Taylor B.W., 2002. The influence of predatory fish on mayfly drift: extrapolating from experiments to nature. Freshwat. Biol., 47, 1497-1513.

Merritt R.W. and Cummins K.W., 1996. An Introduction to the Aquatic Insects of North America. Kendall Hunt, Iowa, $862 \mathrm{p}$.

Mugnai R., Nessimian J.L. and Baptista D.F., 2010. Manual de identificação de macroinvertebrados aquáticos do estado do Rio de Janeiro, Technical Books, Rio de Janeiro, Brazil, $173 \mathrm{p}$.

Naliato D.A.O., Nogueira M.G. and Perbiche-Neves G., 2009. Discharge pulses of hydroelectric dams and their effects in the downstream limnological conditions: a case study in a large tropical river (SE Brazil). Lakes Reserv. Res. Manag., 14, 301-314.

Pérez G.R., 1988. Guía para el estudio de los macroinvertebrados acuáticos del Departamento de Antioquia, Universidad de Antioquia, Bogotá, 217 p.

Poff N.L. and Ward J., 1991. Drift responses of benthic invertebrates to experimental streamflow variation in a hydrologically stable stream. Can. J. Fish. Aquat. Sci., 48, 1926-1936.

Poff N.L. and Zimmerman J.K.H., 2010. Ecological responses to altered flow regimes: a literature review to inform the science and management of environmental flows. Freshwat. Biol., 55, 194-205.

Poff N.L., Allan J.D., Bain M.B., Karr J.R., Prestegaard K.L., Richter B.D., Sparks R.E. and Stromberg J.C., 1997. The Natural Flow Regime. A paradigm for river conservation and restoration. BioScience, 47, 769-784.

Pompeu P.S., Reis L.S., Gandini C.V., Souza R.C.R. and Favero J.M., 2009. The ichthyofauna of upper rio Capivari: defining conservation strategies based on the composition and distribution of fish species. Neotrop. Ichthyol., 7, 659-666.

Ramírez A. and Pringle C.M., 1998. Invertebrate drift and benthic community dynamics in a lowland tropical stream,Costa Rica. Hydrobiologia, 386, 19-26.

Ramírez A. and Pringle C.M., 2001. Spatial and temporal patterns of invertebrate drift in streams draining a Neotropical landscape. Freshwat. Biol., 46, 47-62.

Ríos-Touma B., Prat N. and Encalada A.C., 2012. Invertebrate drift and colonization processes in a tropical Andean stream. Aquat. Biol., 14, 233-246. 
Schreiber E.S.G., 1995. Long-term patterns of invertebrate stream drift in an Australian temperate stream. Freshwat. Biol., 33, 13-25.

Smokorowski K.E., Metcalfe R.A., Finucan S.D., Jones N., Marty J., Power M., Pyrce R.S. and Steele R., 2011. Ecosystem level assessment of environmentally based flow restrictions for maintaining ecosystem integrity: a comparison of a modified peaking versus unaltered river. Ecohydrology, 4, 791-806.

Straskraba M., 1999. Retention time as a key variable of reservoir limnology. In: Tundisi J.G. and Straskraba M. (eds), Theoretical Reservoir Ecology and its Applications, Brazilian Academy of Sciences, São Carlos, 385-410.

Troelstrup N.H. and Hergenrader G.L., 1990. Effect of hydropower peaking flow fluctuations on community structure and feeding guilds of invertebrates colonizing artificial substrates in a large impounded river. Hydrobiologia, 199, 217-228.

Waters T.F., 1972. Drift of stream insects. Annu. Rev. Entomol., $17,253-272$.

Zar J.H., 1996. Biostatistical Analysis, Prentice-Hall, New Jersey, 662 p. 